\title{
In situ suspension feeding behaviour of the pearl oyster, Pinctada margaritifera: combined effects of body size and weather-related seston composition
}

\author{
Stéphane Pouvreau ${ }^{a, b,{ }^{*}}$, Alain Bodoy ${ }^{b}$ and Dominique Buestel ${ }^{c}$
}

\author{
a : CREMA, BP 5, 17137 L'Houmeau, France \\ b : IFREMER COP, BP 7004, Taravao, Tahiti, French Polynesia \\ c : IFREMER-PALAVAS, Chemin de Maguelone, 34250 Palavas, France
}

*: Corresponding author : Tel. : 335465094 40; Fax: 335465006 00; E-mail : spouvrea@ifremer.fr

\begin{abstract}
:
In situ clearance rate (CR) and biodeposition of the black pearl oyster, Pinctada margaritifera, were followed during several field experiments from 1996 to 1998 in the lagoon of Takapoto. Serial measurements of total particulate matter (TPM, $\mathrm{mg} \mathrm{I}^{-1}$ ), particulate inorganic matter (PIM, $\mathrm{mg} \mathrm{I}^{-1}$ ), and particulate organic matter (POM, $\mathrm{mg} \mathrm{I}^{-1}$ ) were related to meteorological conditions, especially wind speed. As a general case, POM and PIM increased with wind speed. Nevertheless, PIM increased faster than POM so that the organic content (OC, \%) of the TPM decreased progressively when wind speed increased. These TPM variations induced direct changes in feeding processes of $P$. margaritifera. CR $\left(\mathrm{I} \mathrm{h}^{-1}\right)$ averaged $22 \mathrm{I} \mathrm{h}^{-1}$ for a pearl oyster of $1 \mathrm{~g}$ dry tissue weight and varied with $\mathrm{POM}, \mathrm{PIM}$ and dry tissue weight $(W, \mathrm{~g})$ according to the following equation: $\mathrm{CR}=26.96$ $\mathrm{PIM}^{-0.42} \mathrm{POM}^{0.96} W^{0.61}$. This clearance activity appeared to be the highest of those mentioned for bivalve species in their natural habitats. Pseudofaecal (PF, $\mathrm{mg} \mathrm{h}^{-1}$ ) production started for very low PIM load (i.e., $0.17 \mathrm{mg} \mathrm{l}^{-1}$ ) and POM load (i.e., $0.28 \mathrm{mg} \mathrm{l}^{-1}$ ) in water and followed the equation: $\mathrm{PF}=32.6(\mathrm{POM}-0.28)(\mathrm{PIM}-0.17) \mathrm{W}^{0.77}$. In other bivalve species, $\mathrm{PF}$ are generally observed for higher PIM or POM levels. These PF were mainly constituted of mineral matter (more than $80 \%$ in weight). Faecal production $\left(\mathrm{F}, \mathrm{mg} \mathrm{h}^{-1}\right)$ increased with seston load and reached progressively a plateau (i.e., maximal intestinal transit time) as shown by the equation describing the faecal biodeposition $\mathrm{F}=20$ $W^{0.49}\left(1-e^{-0.66}\right.$ TPM $)$. The quantity and the composition of the faecal biodeposit were in a range commonly found in literature. This work confirms, by in situ experiments, previous results obtained in laboratory and especially that $P$. margaritifera has developed a trophic strategy which consists of processing large amounts of water to gain sufficient energy in poor waters. But this work also showed that meteorological conditions have indirect influences on feeding processes of pearl oyster by modifying significantly the concentration and the composition of seston.
\end{abstract}




\section{Abstract}

In situ clearance rate and biodeposition of the black pearl oyster, Pinctada margaritifera, were followed during several field experiments from 1996 to 1998 in the lagoon of Takapoto.

Serial measurements of total particulate matter (TPM, $\mathrm{mg} \mathrm{l}^{-1}$ ), particulate inorganic matter (PIM, mg $\mathrm{l}^{-1}$ ), and particulate organic matter (POM, $\mathrm{mg} \mathrm{l}^{-1}$ ) were related to meteorological conditions, especially wind speed. As a general case, POM and PIM increased with wind speed. Nevertheless, PIM increased faster than POM so that the organic content (OC, \%) of the total particulate matter decreased progressively when wind speed increased.

These TPM variations induced direct changes in feeding processes of P. margaritifera. Clearance rate $\left(\mathrm{CR}, \mathrm{l} \mathrm{h}^{-1}\right.$ ) averaged $22 \mathrm{l} \mathrm{h}^{-1}$ for a pearl oyster of $1 \mathrm{~g}$ dry tissue weight and varied with POM, PIM and dry tissue weight $(\mathrm{W}, \mathrm{g})$ according to the following equation : $\mathrm{CR}=26.96 \mathrm{PIM}^{-0.42} \mathrm{POM}^{0.96} \mathrm{~W}^{0.61}$. This clearance activity appeared to be the highest of those mentioned for bivalves species in their natural habitats.

Pseudofaecal production (PF, $\mathrm{mg} \mathrm{h}^{-1}$ ) started for very low PIM load (i.e. $0.17 \mathrm{mg} \mathrm{l}^{-1}$ ) and POM load (i.e. $0.28 \mathrm{mg} \mathrm{l}^{-1}$ ) in water and followed the equation : PF $=32.6$ (POM-0.28)(PIM-0.17) $\mathrm{W}^{0.77}$. In other bivalve species, pseudofaeces are generally observed for higher PIM or POM levels. Theses pseudofaeces were mainly constituted of mineral matter (more than $80 \%$ in weight).

Faecal production (F, $\mathrm{mg} \mathrm{h}^{-1}$ ) increased with seston load and reached progressively a plateau (i.e. maximal intestinal transit time) as shown by the equation describing the faecal biodeposition $\mathrm{F}=20 \mathrm{~W}^{0.49}\left(1-\mathrm{e}^{-0.66 \mathrm{TPM}}\right)$. The quantity and the composition of the faecal biodeposits were in a range commonly found in literature.

This work confirms, by in situ experiments, previous results obtained in laboratory and especially that Pinctada margaritifera has developed a trophic strategy which consists in processing large amounts of water to gain sufficient energy in poor waters. But this work also showed that meteorological conditions have indirect influences on feeding processes of pearl oyster by modifying significantly the concentration and the composition of seston.

Key Words : Tropical bivalve - Tropical lagoon - Filter feeding behaviour - Seston - Clearance rate Biodeposition . 


\section{INTRODUCTION}

Black pearl aquaculture plays a main economic role in French Polynesia. Today, the annual production is six metric tons of pearls. After the large scale mortality which decimated cultivated pearl oysters from several atolls in 1985, French Polynesia decided to set up a general research programme on the pearl oyster, socalled PGRN. As the main objective was to assess the carrying capacity of the lagoon for oyster farming, ecosystem modelling was considered as an useful approach. One of the first steps in ecological modelling consists in building a physiological model accounting for the growth of the cultivated bivalve. Such models have already been achieved for various species of farmed molluscs (Ross and Nisbet, 1990; Bacher et al., 1991; Schneider, 1992; Willows, 1992; Raillard et al., 1993; Van Haren and Kooijman, 1993; Barillé et al., 1997b) but none has been proposed until now for the growth of the black-lipped pearl oyster, Pinctada margaritifera (Linné, 1758) var. cumingi (Reeve), in a lagoon environment.

To set up such a growth model, the physiological functions which govern gains and losses in the bivalve budget have to be known. Up to now, few works have focused on the physiology of P. margaritifera : a first estimation of clearance rate under realistic laboratory conditions, with algal concentrations similar to those found in Polynesian lagoons, showed that pearl oysters have the ability to process large volume of water (Jonquières et al., 1995; Pouvreau et al., 1998a). In a recent study, Yukuhira et al. (1998) working in Australian waters also came to the same conclusion ; that $P$. margaritifera as well as $P$. maxima are « ...exceptional bivalves in terms of energy fluxes. ». Moreover, Pouvreau et al. (1999) showed that the pearl oyster was unable to efficiently catch pico-particles $(<2 \mu \mathrm{m})$, whereas a great part of organic matter in the lagoon environment is close to $1 \mu \mathrm{m}$. To explain the paradoxically fast growth of pearl oysters in such poor waters, these authors pointed out that clearance activity is so high that $>2 \mu \mathrm{m}$ particles provided sufficient energy to the bivalve.

However, connections to field conditions are not concrete in these 4 previous works. Pouvreau et al. (1998b) showed that seston parameters vary according to meteorological conditions. So, effects of these variations (even restricted) on feeding processes have to be taken into consideration in order to compute an in situ realistic growth model. In situ relationships between feeding behaviour and seston variations have been widely studied in other bivalves (e.g. Bayne et al., 1993; De Villiers and Hodgson, 1993; Iglesias et al., 1996; Ward and MacDonald, 1996; Arifin and Bendell-Young, 1997; Barillé et al., 1997a; Bacon et al., 1998; Cranford et al., 1998; MacDonald et al., 1998; Hawkins et al., 1998a, b for the most recent) but had 
never been investigated in P. margaritifera in its natural lagoon environment. Recently, Hawkins et al. (1998b) gave some details on in situ feeding processes of P. margaritifera (erroneously named margarifera) in a different environment, a mangrove system in Malaysia. Water temperature is almost identical between Malaysia and Polynesia (around $28^{\circ} \mathrm{C}$ ). But, on the other hand, in the mangrove, seston abundance (TPM) is higher, i.e. from 6 to $40 \mathrm{mg} \mathrm{l}^{-1}$, the organic content (6 to 22\%) and the salinity (27.9 \%) are lower compared to water of the Takapoto lagoon, characterised by very low TPM values (around $1 \mathrm{mg} \mathrm{l}^{-1}$ ), high organic content (>50 \%) and high salinity (39\%). Such differences between environment presumably influence $P$. margaritifera feeding processes : Hawkins et al. (1998b) measured effectively low CR in Malaysian waters compared to those obtained in Polynesian waters by Jonquières et al. (1995) and Pouvreau et al. (1998a, 1999). The aim of the present study is to directly estimate feeding processes of pearl oyster in its lagoon environment for various seston concentration and composition.

Several methods are used to estimate bivalves feeding processes, especially clearance rate, CR, (see Coughlan, 1969 ; Widdows, 1985 ; Iglesias et al., 1998). CR can be evaluated from the decrease in particle concentration in water surrounding the bivalve ; however, this method cannot be easily used during field experiments without disturbing the bivalves. Furthermore it does not allow the quantification of pseudofaecal products, which constitutes the first source of energy loss. On the other hand, the biodeposition method (Iglesias et al., 1992 ; Cranford and Hargrave, 1994 ; Iglesias et al., 1998) is easy to set up in situ and the results reflect the studied bivalve behaviour.

In the present work, in situ biodeposition rate (pseudofaeces, PF, and faeces, F) and clearance rate (CR) were quantified in relation to pearl oyster body size in the lagoon of Takapoto Atoll (Tuamotu Island - French Polynesia). As the feeding behaviour may change according to weather-induced changes in temperature and particulate matter, these measurements were obtained for different meteorological conditions. In order to precisely relate environment and feeding behaviour of the bivalves, mathematical formulations are proposed for CR, PF and F production of P. margaritifera in lagoons. These mathematical functions will be integrated in a deterministic growth model in future work. 


\section{MATERIALS AND METHODS}

\section{Physical environment}

The study was carried out in the SW lagoon of Takapoto Atoll (Tuamotu Island, French Polynesia). This atoll (Latitude $14^{\circ} 30^{\prime} \mathrm{S}$, and longitude $145^{\circ} 20^{\prime} \mathrm{W}$ ) is $18.7 \mathrm{~km}$ long and $4.4 \mathrm{~km}$ wide with an area of $81.7 \mathrm{~km}^{2}$ (Sournia and Ricard, 1976). Mean depth of the lagoon is $23 \mathrm{~m}$, with a maximum of $55 \mathrm{~m}$. Volume of water is estimated between $1.3 \mathrm{~km}^{3}$ (Sournia and Ricard, 1976) and $2.28 \mathrm{~km}^{3}$ (Yann Morel, pers. comm.). Because of restricted exchange with the ocean, the average residence time of water is estimated at 4 years, and total replacement at 17 years (Sournia and Ricard, 1976). No tidal current is observed in the lagoon (absence of channel into the coral ring), so the mass of water could only be stirred and homogenised by regular trade winds. Therefore, spatial variations of the potential food for cultivated pearl oysters (i.e. particulate organic matter in suspension, POM) are low in this lagoon whereas temporal variations strongly correlated with meteorological events were often observed (Pouvreau et al., 1998b). In that respect, the experiments were carried out at various seasons in order to encounter different weather conditions.

\section{Field experiments}

Sampling scheme : Three field investigations were performed from June 1996 to November 1997. The first survey (June 1996) corresponded to the beginning of austral winter (lower temperature, higher atmospheric pressure, low precipitation), the second occurred in March 1997 during the austral summer (higher temperature, lower atmospheric pressure, and heavy rains), and the third occurred during November 1997 (intermediary season). Each field trip lasted 10 days. The experiment consisted of : (1) separately collecting all the faeces and pseudofaeces biodeposits produced by oysters of various size over several 24h-cycles and (2) following the variations in particulate organic and inorganic matter (POM and PIM, mg $\mathrm{l}^{-1}$ ) during the same time. Twenty series of biodeposition measurements were performed during the 3 field trips.

Biological material : One hundred ninety six pearl oysters in a size range from 5 to $18 \mathrm{~cm}$ shell height (i.e. 1 to 5 years of age) were used. During each of the 3 surveys, pearl oysters were collected from long-lines located in the SW extremity of Takapoto lagoon. They were cleaned of epibionts and then transferred to a line (6 m deep) near the field sub-marine experimental facilities, where they were hung for an acclimatisation 
period of two days (or more) in order to avoid stress during measurements. After each experiment, the pearl oysters were analysed for height $(\mathrm{H}$, dorso-ventral axis), dry soft tissue weight (W, obtained from freezedrying) and dry shell weight ( $\mathrm{W}_{\text {shell, }}$, obtained from drying at $60^{\circ} \mathrm{C}$ during $\left.48 \mathrm{~h}\right)$. Each of the physiological functions presented in this work depend upon the dry tissue weight (W, g).

Feeding behaviour and experimental design : In order to build an efficient biodeposits collector, preliminary diving observations were necessary to describe in situ behaviour and biodeposits processing of pearl oysters. These observations (Buestel, unpublished) revealed that bundles of white, sticky pseudofaeces, entangled in mucus were carried slowly along the inside edge of the mantle, from the labial palps to the palleal fold at the extremity of gills. They were then rejected outside and fell vertically. On the other hand, the brown faeces arriving in the supra-branchial chamber were discharged in the powerful exhalant water current (Fig. 1).

According to these observations, a simple apparatus devoted to quantitatively collect and separate PF and F biodeposits was conceived. Four pearl oysters were fixed on a round PVC plate (80 $\mathrm{cm}$ in diameter). A hole was drilled in the plate, adjusted under the point of reception of pseudofaeces. Four collectors (pots) were screwed under the plate, so that the pseudofaeces could sink in. Faeces were collected as follows : 4 cylindrical pipes of $10 \mathrm{~cm}$ wide and $80 \mathrm{~cm}$ long were fixed horizontally, just behind each of the four pearl oysters, completely channelling the exhalant current, so that the faeces carried out by the exhalant current settled in the pipe. At the end of biodeposits collection, each pot and pipe was carefully unscrewed by a diver and closed by a screwed-cap. The size of the pipe and collectors were adapted to the oysters size, in order to avoid losses of biodeposits, to obtain a better separation between faeces and pseudofaeces, and to minimise the stress for the individuals. Finally, such apparatus allowed (1) to quantitatively collect biodeposits, except for the very large pearl oyster (6 years old and more) for which the losses being estimated as less than 5\% ; (2) to efficiently separate the pseudofaeces from the faeces (if some melting occurred, manual intervention was still possible, thanks to the great differences in colour and form between PF and F) ; (3) to avoid the natural sedimentation in horizontal pipes and to assess it in the vertical collectors by means of control collectors. This biodeposits collector was preliminary tested before in situ experimentation, and showed a good efficiency when natural water currents were low (less than $0.1 \mathrm{~m} \mathrm{~s}^{-1}$ ), a condition always encountered 
during the study inside the lagoon. Five biodeposits collectors composed of four units were built, so that a maximum of 20 pearl oysters could be simultaneously sampled.

Experimental procedures : During each survey, pearl oysters were transferred on the submarine biodeposits collectors and we waited for a $24 \mathrm{~h}$ acclimation period which allowed collection of representative faeces in a cord form, indicating that the intestinal transit was complete. Regular scuba-diving ensured that pearl oysters remained open. Closed or inactive oysters were discarded. Collection of biodeposits began at $09 \mathrm{~h}$ and was performed during $24 \mathrm{~h}$, in order to cover a complete night and day cycle.

Meteorological and hydrobiological parameters : Meteorological data (air temperature, atmospheric pressure, precipitation, wind speed and direction) were obtained by Meteo-France. Physical parameters of water (temperature, salinity and oxygen content) were continuously monitored using an automatic acquisition station. Particulate matter was measured during each 24 h cycle, as follows : 3 samples (5 l) of water were collected every $3 \mathrm{~h}$ by pumping, near the biodeposits facilities at $6 \mathrm{~m}$ depth and filtered on 47 mm GF/C filters ( $\mathrm{n}=27$ for each cycle). After a careful rinsing with isotonic ammonium formate, filters were dried overnight at $60^{\circ} \mathrm{C}$ and weighed to obtain the Total Particulate Matter (TPM, mgl ${ }^{-1}$ ) in suspension. Ash remaining after a complete combustion at $500^{\circ} \mathrm{C}$ during at least $4 \mathrm{~h}$ gave an estimate of the Particulate Inorganic Matter (PIM, $\mathrm{mg} \mathrm{l}^{-1}$ ) and losses by ignition an estimate of the Particulate Organic Matter (POM, $\mathrm{mg} \mathrm{l}^{-1}$ ). For each $24 \mathrm{~h}$ cycle, the daily mean of TPM, PIM and POM was then computed on at least 27 values. The ratio of organic content (OC, \%) indicated the quality of the seston.

\section{Physiological determinations}

Biodeposits measurements : PF and F productions (mg dry wt $\mathrm{h}^{-1}$ ) were calculated for active pearl oysters. Diving observations showed that the " apparent " activity time (T) of pearl oysters was generally around $24 \mathrm{~h}$ per day, since in lagoons pearl oysters are never emerged. The following data were collected :

PF : Production of pseudofaeces (mg dry wt. $h^{-1}$ )

$\mathrm{PF}_{\mathrm{PIM}}$ : Production of pseudofaeces, inorganic part (mg ash dry wt. $\mathrm{h}^{-1}$ )

$\mathrm{PF}_{\mathrm{POM}}$ : Production of pseudofaeces, organic part (mg ash-free dry wt. $\mathrm{h}^{-1}$ )

$\mathrm{OC}_{\mathrm{PF}}$ : Organic content of pseudofaeces.

Similar notations were used for faeces production (F, $F_{\text {PIM }}, F_{\text {POM }}, O_{F}$ ). 
Clearance rate : Clearance rate $\left(\mathrm{CR}, \mathrm{l} \mathrm{h}^{-1}\right)$ was calculated by using the biodeposits method (Iglesias et al., 1992 ; reviewed by Iglesias et al., 1998). This method is based on the assumption that inorganic matter is not significantly absorbed during digestion (Cranford and Grant, 1990) : the sum of ash weight contained in pseudofaeces and faeces $\left(\mathrm{PF}_{\mathrm{PIM}}+\mathrm{F}_{\mathrm{PIM}}\right)$ is then equal to the weight of inorganic matter retained on the gill. The clearance rate $\left(\mathrm{CR}, \mathrm{l} \mathrm{h}^{-1}\right)$, i.e. volume of water totally cleared of particles per $\mathrm{h}$, is calculated as follows :

$$
\mathrm{CR}=\left(\mathrm{PF}_{\mathrm{PIM}}+\mathrm{F}_{\mathrm{PIM}}\right) / \mathrm{PIM} \text {. }
$$

Pumping rate $\left(\mathrm{PR}, \mathrm{l} \mathrm{h}^{-1}\right)$, i.e. the amount of water which pass through the gill, was estimated from CR assuming that PIM particles are retained with a 100\% efficiency. Since size of PIM particles are generally above $2 \mu \mathrm{m}$ (Buigues, 1982), this assumption is reasonable.

Mathematical formulation : Clearance rate (CR), PF and F production were modelled according to environmental (TPM, PIM or POM) or internal (W) parameters. Model building was based on : (1) biological assumptions, from the literature analysis, completed by diving or laboratory observations by the authors, and (2) statistical criteria. Biological assumptions were the following :

(1) All physiological functions are related with the body size of bivalves by a common allometric relationship (review by Bayne and Newell, 1983, and Winter, 1976). In this respect, physiological functions have to be expressed as follows : $\mathrm{Y}=\mathrm{f}\left(\mathrm{W}^{\text {allom }}\right)$, where allom is called the allometric exponent. As a general case, allometric exponent is around 0.67 (see review in Pouvreau et al., 1999).

(2) The seston load and composition may influence PR or CR (Foster-Smith, 1975; Winter, 1976; Barillé and Prou, 1993; De Villiers and Hodgson, 1993; Defossez and Daguzan, 1995; Iglesias et al., 1996; Ward and MacDonald, 1996; Arifin and Bendell-Young, 1997) even in low turbidity water (MacDonald and Ward, 1994). For example, PR is positively correlated to POM or chlorophyll a (Cranford and Gordon, 1992; MacDonald and Ward, 1994). Alternatively, PIM may have a negative effect on PR (Barillé and Prou , 1993 ; Ward and MacDonald, 1996). Accordingly, PR or CR would be expressed as follows : $Y=f\left(T P M\right.$ or PIM, POM, $\left.W^{\mathrm{b}}\right)$.

(3) Biodeposit production increases with the seston load (De Villiers and Hodgson, 1993; Cranford and Hargrave, 1994; MacDonald and Ward, 1994; Ward and MacDonald, 1996; Arifin and 
Bendell-Young, 1997; Barillé et al., 1997a; Hawkins et al., 1998a). However, some mechanisms are specific to PF or F production.

- PF production results from a complicated crossed effect of PIM and POM, because of sorting efficiency. Below a minimal value of PIM or POM, PF production appears (Barillé et al., 1997a) ; this so-called PF treshold may be different for POM and PIM. Above these values, PF production increases according to PIM and POM concentration. Then, PF production would be expressed as follows : PF=f [(PIM-PIM min $_{\text {, }}$,

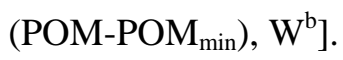

- F production increases with the seston load until maximal intestinal transit time is reached, the gut being full. Afterwards, F production remains constant with a plateau $F_{\max }$ (Barillé et al., 1997a). To take into account this threshold effect for high TPM values, an asymptotic term (i.e. 1-e ${ }^{-k . T P M}$ ) was added in the equation proposed for faecal production. Nevertheless, in low TPM conditions, F production may often be below the theoretical $F_{\max }$ value. So, $F_{\max }$ was fitted by eye for a $1 \mathrm{~g}$ dry tissue weight pearl oyster, looking at the entire set of data and was called $F_{\text {max-1g }}$. Then, $F$ production model is expressed as follows $: F=f\left(F_{\text {max }-1 \mathrm{~g}},\left(1-\mathrm{e}^{-\mathrm{k} \cdot \mathrm{TPM}}\right), \mathrm{W}^{\mathrm{b}}\right)$.

By considering the previous biological assumptions and after several tests, the most appropriate equations retained for summarising the main physiological processes are :

$$
\begin{aligned}
& \mathbf{C R}=\mathrm{a}\left(\mathrm{POM}^{\mathrm{y}} \cdot \mathrm{PIM}^{\mathrm{z}}\right) \cdot \mathrm{W}^{\mathrm{b}} \\
& \mathbf{P F}=\mathrm{a}^{\prime}\left(\mathrm{POM}-\mathrm{POM}_{\min }\right) \cdot\left(\mathrm{PIM}-\mathrm{PIM}_{\min }\right) \cdot \mathrm{W}^{\mathrm{c}} \\
& \mathbf{P F}_{\mathbf{P I M}}=\mathrm{a},{ }^{\prime}\left(\mathrm{POM}-\mathrm{POM}_{\min }\right) \cdot\left(\mathrm{PIM}-\mathrm{PIM}_{\min }\right) \cdot \mathrm{W}^{\mathrm{C}^{\prime}} \\
& \mathbf{P F}_{\mathbf{P O M}}=\mathrm{a},{ }^{\prime}\left(\mathrm{POM}-\mathrm{POM}_{\min }\right) \cdot\left(\mathrm{PIM} \mathrm{PIM}_{\min }\right) \cdot \mathrm{W}^{\mathrm{c}}
\end{aligned}
$$

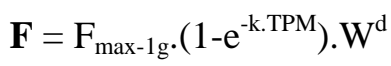

$$
\begin{aligned}
& \mathbf{F}_{\text {PIM }}=F_{\text {max }-1 \mathrm{~g} \cdot} \cdot\left(1-\mathrm{e}^{-\mathrm{k}^{\prime} \cdot \mathrm{TPM}}\right) \cdot \mathrm{W}^{\mathrm{d}^{\prime}} \\
& \mathbf{F}_{\text {POM }}=F_{\text {max }-1 \mathrm{~g} \cdot} \cdot\left(1-\mathrm{e}^{-\mathrm{k}^{\prime \prime} \cdot \mathrm{TPM}}\right) \cdot \mathrm{W}^{\mathrm{d}},
\end{aligned}
$$

where the superscript letters (b, c, c', c', d, d' and d') correspond to the allometric exponent for each physiological function.

Parameters were all fitted by least-squares non-linear regressions (Marquardt, 1963). Statistical analysis were conducted under Statgraphic's Plus software. When useful, these functions were standardised to represent values for an oyster of $1 \mathrm{~g}$ dry tissue weight by using the following formula: $\mathrm{Y}_{\text {standardised }}=\mathrm{Y}_{\text {measured }} * \mathrm{~W}^{\text {-allom }}$ with allom equal to the allometric exponent estimated in equations (a) to (g). 


\section{RESULTS}

\section{Hydrobiological conditions}

Meteorological characteristics : During the first cruise (June 1996), the weather was dry and sunny and conditions encountered (Table 1) are representative of the austral winter (fresh and dry season). In March 1997 (cruise 2), two different weather conditions were observed : a very sunny and hot weather and a fresh and cloudy weather with rainfall and irregular westward. These conditions were characteristic of the austral summer (hot and rainy season with low pressures). The last field trip was characterised by increasing E-SE winds, whose local name is " Mara'amu " and by scarce light rain (increasing at the end of the field trip). These conditions, often encountered during austral winter, are uncommon in November, and may be due to the occurrence of El Niño Southern Oscillation in 1997.

Particulate matter characteristics : The mean total particulate matter (TPM) was around $1 \mathrm{mg} \mathrm{l}^{-1}$ during the 3 surveys, with $60 \%$ of organic matter (OC, Table 1). However, day-to-day variations of TPM in quantity and quality was noticed in relation to the wind conditions (Fig. 2) :

- During experiment 1 , POM remained constant near $0.63 \mathrm{mg} \mathrm{l}^{-1}$, whereas PIM showed a slow decrease from $0.48(\mathrm{CI}=0.10 ; \mathrm{n}=27)$ to $0.26 \mathrm{mg} \mathrm{l}^{-1}(\mathrm{CI}=0.06 ; \mathrm{n}=27)$.

- During experiment 2, the highest value of TPM (1.25 $\mathrm{mg} \mathrm{l}^{-1}$; CI=0.15; $\left.\mathrm{n}=15\right)$ was reached for a maximal wind velocity $\left(25 \mathrm{~km} \mathrm{~h}^{-1}\right)$ at the middle of the survey. Afterwards, TPM showed a slow decrease, simultaneous to the wind velocity decrease (Fig. 2). At the end of the survey, TPM was equal to $0.81 \mathrm{mg} \mathrm{l}^{-1}(\mathrm{CI}=0.05 ; \mathrm{n}=15)$.

- During experiment 3, TPM values showed a characteristic pattern. TPM was low at the beginning of the survey averaging $0.70 \mathrm{mg} \mathrm{l}^{-1}(\mathrm{CI}=0.09$; $\mathrm{n}=18)$ and mainly composed of organic matter (OC>60\%). TPM increased during the survey, reaching $1.29 \mathrm{mg} \mathrm{l}^{-1}(\mathrm{CI}=0.13 ; \mathrm{n}=18)$, whereas the OC decreased slowly to 50\%. TPM pattern was easily related to wind velocity pattern exhibiting the same progressive increase (Fig. 2). 


\section{Physiological functions}

Clearance rate : CR (Fig. 3a) varied from approximately 10 for a young pearl oyster $(<1 \mathrm{~g}$ dry tissue weight) to more than $120 \mathrm{l} \mathrm{h}^{-1}$ for a 5-year old pearl oyster (> $10 \mathrm{~g}$ dry tissue weight). When computing the correlation coefficient matrix (Table 2), it appeared that $\mathrm{W}$ was the prominent factor acting on $\mathrm{CR}$ ( $\mathrm{r}=0.79$, $P<0.0001)$. Concerning seston, Table 2 showed that seston composition had more of an effect than seston concentration. Indeed, POM (and related OC) also had a significant effect ( $\mathrm{r}=0.32, P<0.0001$ ), PIM had a small negative effect on CR ( $\mathrm{r}=-0.08, P=0.05)$, whereas total seston concentration, TPM, had virtually no effect $(P>0.1)$ in the range of values encountered in this lagoon. A regressive model was computed on CR data to take into account all these effects, as follows :

$$
\begin{gathered}
\mathbf{C R}=26.96( \pm 2.52 \mathrm{SE}) \bullet \mathbf{P I M}^{-0.42( \pm 0.05 \mathrm{SE})} \bullet \mathbf{P O M}^{0.96( \pm 0.11 \mathrm{SE})} \bullet \mathrm{W}^{0.61( \pm 0.04 \mathrm{SE})} \\
\left(\mathrm{n}=196, \mathrm{R}^{2}=0.75, \mathrm{~F}_{\text {ratio }}=1179.95, P<0.05\right)
\end{gathered}
$$

Data were adequately fitted by the model (Fig. 4) : the residual analysis did not reveal any unforeseen trend and the residual distribution was not asymmetric (coefficient of skewness $=0.01$ ). For typical values of PIM and POM encountered in the lagoon, a tri-dimensional representation (Fig. 5a) showed that the CR increased with pearl oyster size, while remaining fairly independent of POM or PIM variations. The lower CR values $\left(<5 \mathrm{l} \mathrm{h}^{-1}\right)$ were observed for small individual $\left(0.1 \mathrm{~g}\right.$ dry tissue weight) and the higher values (95 $\left.\mathrm{l} \mathrm{h}-{ }^{1}\right)$ for larger individual (11 g dry tissue weight).

For a theoretical range of variation in PIM and POM, the standardised values of CR (Fig. 5b) varied between $12.6 \mathrm{l} \mathrm{h}^{-1} \mathrm{~g}^{-1}$, for low values of POM $\left(0.37 \mathrm{mg} \mathrm{l}^{-1}\right)$ and high values of PIM (0.65 mg l-1 $)$, and $35.4 \mathrm{l} \mathrm{h}^{-1} \mathrm{~g}^{-1}$ for high POM (0.66 $\left.\mathrm{mg} \mathrm{l}^{-1}\right)$ and low PIM (0.20 $\left.\mathrm{mg} \mathrm{l}^{-1}\right)$. When POM and PIM varied according to the typical pattern encountered frequently in the lagoon, standardised values of CR showed less variation and remained fairly constant around $22 \mathrm{l} \mathrm{h}^{-1} \mathrm{~g}^{-1}$ (dark bold line in Fig. 5b).

Pseudofaeces production : The PF production was clearly related to W and TPM (Fig. 3b). For low TPM ( $\left.<0.60 \mathrm{mg} \mathrm{l}^{-1}\right)$, there was no significant PF production $\left(<1 \mathrm{mg} \mathrm{h}^{-1}\right)$, the PF-threshold being just below this TPM value. Maximal values for PF production (approx. $35 \mathrm{mg} \mathrm{h}^{-1}$ ) were observed for 5 year-old pearl oysters exposed to high seston load $\left(1.25 \mathrm{mg} \mathrm{l}^{-1}\right)$. Within these two limits, various PF production values were observed, depending on W, PIM and POM. The model minimising as well as possible the sum of squares was as follows : 


$$
\begin{gathered}
\mathbf{P F}=32.57( \pm 6.43 \mathrm{SE}) \bullet[\mathrm{POM}-0.28( \pm \mathbf{0 . 0 5} \mathrm{SE})] \bullet[\mathrm{PIM}-\mathbf{0 . 1 7}( \pm \mathbf{0 . 0 2} \mathrm{SE})] \bullet \mathrm{W}^{0.77( \pm 0.06 \mathrm{SE})} \\
\left(\mathrm{n}=196, \mathrm{R}^{2}=0.75, \mathrm{~F}_{\text {ratio }}=424.25, P<0.05\right)
\end{gathered}
$$

PF were mainly constituted of mineral matter (more than $80 \%$, Fig. 3c). OC $_{\mathrm{PF}}$ showed a progressive decrease from $20 \%$ for low values of TPM , to $10 \%$ when TPM was high (Fig. 6). Regressive models on organic mineral parts of PF production data were as follows :

$$
\begin{gathered}
\mathbf{P F}_{\mathrm{PIM}}=\mathbf{3 2 . 1 6}( \pm \mathbf{6 . 0 0} \mathrm{SE}) \bullet[\mathrm{POM}-\mathbf{0 . 3 0}( \pm \mathbf{0 . 0 4} \mathrm{SE})] \bullet[\mathrm{PIM}-\mathbf{0 . 1 6}( \pm \mathbf{0 . 0 2} \mathrm{SE})] \bullet \mathrm{W}^{0.74( \pm 0.06 \mathrm{SE})} \\
\left(\mathrm{n}=196, \mathrm{R}^{2}=0.75, \mathrm{~F}_{\text {ratio }}=429.09, P<0.05\right) \\
\mathbf{P F}_{\mathrm{POM}}=\mathbf{0 . 5 2}( \pm \mathbf{0 . 5 5} \mathrm{SE}) \bullet[\mathrm{POM}+\mathbf{1 . 0 6}( \pm \mathbf{1 . 7 5} \mathrm{SE})] \bullet[\mathrm{PIM}-\mathbf{0 . 1 9}( \pm \mathbf{0 . 0 2} \mathrm{SE})] \bullet \mathrm{W}^{0.97( \pm 0.08 \mathrm{SE})} \\
\left(\mathrm{n}=196, \mathrm{R}^{2}=0.69, \mathrm{~F}_{\text {ratio }}=294.43, P<0.05\right)
\end{gathered}
$$

For the last equation, the POM-threshold parameter was not significant (large SE), and allometric coefficient was close to 1 . A more simple equation was then computed :

$$
\begin{aligned}
\mathbf{P F}_{\text {POM }}= & \mathbf{1 . 3 4}( \pm \mathbf{0 . 0 9} \mathrm{SE}) \bullet \mathbf{P O M} \bullet[\mathrm{PIM}-\mathbf{0 . 1 8}( \pm \mathbf{0 . 0 2} \mathrm{SE})] \bullet \mathbf{W} \\
& \left(\mathrm{n}=196, \mathrm{R}^{2}=0.69, \mathrm{~F}_{\text {ratio }}=583.66, P<0.05\right)
\end{aligned}
$$

The $\mathrm{R}^{2}$ values indicated a good agreement between model and field observations (Fig. 4). A residual analysis did not reveal any typical trend, and the coefficient of skewness never exceeded 0.6.

The theoretical PIM-threshold for PF production was nearly the same for the 3 equations, and therefore an average value of $0.17( \pm 0.02 \mathrm{SE}) \mathrm{mg} \mathrm{l}^{-1}$ could be considered. The POM-threshold could only be defined for $\mathrm{PF}$ and $\mathrm{PF}_{\mathrm{PIM}}$ : it was close to $0.29( \pm 0.04 \mathrm{SE}) \mathrm{mg} \mathrm{l}^{-1}$. The allometric effect of $\mathrm{W}$ was only significant on PF and $\mathrm{PF}_{\mathrm{PIM}}$ with a value of 0.75 ( $\pm 0.06 \mathrm{SE}$ ). Results tended to show that $\mathrm{PF}_{\mathrm{POM}}$ followed a pattern different from $\mathrm{PF}_{\mathrm{PIM}}$, presumably because of mucus production which was not assessed, while it may constitute a significant part of the organic content in PF.

For typical seston values encountered in the lagoon, 3-D figures showed that calculated PF production varied from 0 to $40 \mathrm{mg} \mathrm{h}^{-1}$ according to W, PIM and POM (Fig. 5c and 5d). Standardised values of the PF production varied from 0 to $6 \mathrm{mg} \mathrm{h}^{-1} \mathrm{~g}^{-1}$ according to the crossing effect of PIM and POM.

Faeces production : F production was clearly related to $\mathrm{W}$ and more weakly to TPM (Fig. 3e). The minimal values were around 5 for a young pearl oyster, and reached $40 \mathrm{mg} \mathrm{h}^{-1}$ for oldest individuals. The general model for F production was :

$$
\mathrm{F}=\mathrm{F}_{\max -1 \mathrm{~g}} \bullet \mathrm{W}^{0.49( \pm 0.03 \mathrm{SE})} \bullet\left(1-\mathrm{e}^{-0.66( \pm 0.06 \mathrm{SE}) \mathrm{x} \text { TPM }}\right)
$$




$$
\left(\mathrm{n}=196, \mathrm{R}^{2}=0.66, \mathrm{~F}_{\text {ratio }}=2040.20, P<0.05\right)
$$

An assessment of $F_{\max -1 g}$ was made from the entire set of data. When looking at Fig. 3, the highest values of $F$ production never exceeded $20 \mathrm{mg} \mathrm{h}^{-1} \mathrm{~g}^{-1}$ even for the highest seston load ( 1.5 mg l-1). So $\mathrm{F}_{\text {max-1g }}$ was considered equal to $20 \mathrm{mg} \mathrm{h}^{-1} \mathrm{~g}^{-1}$.

The faeces were mainly constituted of mineral matter (more than $80 \%$, Fig. 3f) and $\mathrm{F}_{\mathrm{POM}}$ (Fig. 3g) was very low as $\mathrm{PF}_{\mathrm{POM}}$. To take into account the specific composition of faecal biodeposits, two others models was computed :

$$
\begin{gathered}
\mathbf{F}_{\text {PIM }}=20 \bullet \mathrm{W}^{0.47( \pm 0.03 \mathrm{SE})} \bullet\left(\mathbf{1}-\mathbf{e}^{-0.56( \pm 0.05 \mathrm{SE}) \times \mathrm{TPM}}\right) \\
\left(\mathrm{n}=196, \mathrm{R}^{2}=0.64, \mathrm{~F}_{\text {ratio }}=1872.61, P<0.05\right) \\
\mathbf{F}_{\text {POM }}=\mathbf{2 0} \bullet \mathrm{W}^{0.59( \pm 0.04 \mathrm{SE})} \bullet\left(\mathbf{1}-\mathbf{e}^{-0.06( \pm 0.00 \mathrm{SE}) \times \mathrm{TPM}}\right) \\
\left(\mathrm{n}=196, \mathrm{R}^{2}=0.67, \mathrm{~F}_{\text {ratio }}=1747.63, P<0.05\right)
\end{gathered}
$$

When plotting observed values against computed ones, a good fit was observed (Fig. 4). No suspicious trend could be extracted from residual analysis. The exponential coefficient was around 0.5 for $\mathrm{F}_{\mathrm{PIM}}$, but was higher for $\mathrm{F}_{\mathrm{POM}}$. As observed for the PF production, the organic matter in faeces followed a pattern slightly different to mineral matter.

For typical seston values encountered frequently in Takapoto lagoon, a 3-D representation (Fig. 5e and 5f) showed that the calculated $\mathrm{F}$ production varied from 2 to $38 \mathrm{mg} \mathrm{h}^{-1}$. Standardised values of $\mathrm{F}$ production varied from 6 to $12 \mathrm{mg} \mathrm{h}^{-1} \mathrm{~g}^{-1}$ depending on the TPM level. 


\section{Discussion}

\section{Seston composition}

Suspended particulate organic matter is low in Polynesian lagoon waters. In this study, TPM never exceed values above $2 \mathrm{mg} \mathrm{l}^{-1}$ and the mean value of POM was approx. equal to $0.6 \mathrm{mg} \mathrm{l}^{-1}$. These data are consistent with previous studies performed on this lagoon by numerous authors (e.g. Sournia and Ricard, 1976 ; Charpy et al., 1997 ; Charpy and Blanchot, 1998).

The particulate matter is mainly constituted of detritus (more than $60 \%$, Blanchot et al., 1989). The 40\% living part is composed of cyanobacteria (Charpy et al., 1992 ; Charpy and Blanchot, 1996), free living bacteria (Dufour and Torréton, 1996), picoeukaryotes (Charpy and Blanchot, 1996 ; 1998), micro-algae and protozoa (Blanchot et al., 1989 ; Loret, 1998).

Our results suggest that a part of the suspended organic matter (sometimes $>50 \%$ of TPM) is due to resuspension processes and, then, may have a benthic origin. Sand or mud of Polynesian lagoons bottom are well-known to be highly productive (Sournia, 1976) so that resuspension processes may incorporate significant input in the water column, especially in shallow areas.

The potential role played by the benthic production in the entire water column has never been studied in Takapoto lagoon. In another environment, Arfi et al. (1993) showed a strong correlation between PIM, chlorophyll $a$ and wind, and concluded that in shallow areas, wind induced increase in available food for planktonic feeders, and constituted the major factor controlling the productivity of the system.

In a very static and closed system as Takapoto lagoon, it is tempting to speculate that wind may play a significant role in increasing the potential amount of food for cultivated pearl oysters, by way of resuspension processes and water mixing. Size of the particulate matter which is resuspended is not known, but these particles are generally embedded in mucus to constitute large and fragile structure called aggregates or «marine snow » (Johannes, 1967 ; Marshall, 1968; Coles and Strathmann, 1973). Since size of marine snow is generally higher than $2 \mu \mathrm{m}$, it would be retained on pearl oyster gills with a high efficiency (Pouvreau et al., 1999). 


\section{Trophic strategy of pearl oyster}

In the range of typical seston values encountered in the lagoon, in situ clearance rate of Pinctada margaritifera can be approximated by the general equation $\mathrm{CR}$ (in $\mathrm{l} \mathrm{h}^{-1}$ ) $=22 \mathrm{~W}^{0.61}$ (in g). The proportionality coefficient of this equation ( $a$-value), equal to $22.0 \mathrm{l} \mathrm{h}^{-1} \mathrm{~g}^{-1}$, is the highest ever mentioned in bivalve literature. From laboratory experiments (Pouvreau et al., 1999), a similar value (25.9 $\mathrm{l} \mathrm{h}^{-1}$ ) was estimated, by using various methods different from those in this study. The concordance between these data showed that: (1) laboratory conditions of Pouvreau et al. (1999) faithfully mimicked Polynesian lagoonal conditions, and (2) the new method used in the present work to estimate in situ clearance rate is reliable. Yukuhira et al. (1998) also measured high clearance activity in Pinctada sp., but the $a$-value found by these authors was slightly lower $\left(12.3 \mathrm{l} \mathrm{h}^{-1}\right)$, probably because of laboratory conditions. Working in situ in a Malaysian mangrove, Hawkins et al. (1998b) concluded also that clearance activity in Pinctada sp. was higher than in temperate species. They found a lower $a$-value (approx. $5.5 \mathrm{l} \mathrm{h}^{-1} \mathrm{~g}^{-1}$ ), but for a range of TPM from 10 to $23 \mathrm{mg} \mathrm{l}^{-1}$, i.e. more than 10 times higher than in the present study. These various data suggest a direct relationship between TPM and CR, and further experimentation should be conducted to establish an accurate model for a large range of seston concentrations and compositions.

In Polynesian atoll lagoons, large variations in TPM are never encountered (Charpy et al., 1997) except during a cyclone which remains a scarce event in French Polynesia. On the other side, wind-induced resuspension processes involve small variations in seston quantity and quality(organic content) which exhibit small variations in feeding processes. In this way, our CR model has been improved in comparison with Pouvreau et al. (1999) by incorporating PIM and POM effects. The new formulation, CR = 26.96 PIM $^{-}$ ${ }^{0.42} \mathrm{POM}^{0.96} \mathrm{~W}^{0.61}$, shows that POM has a positive effect whereas PIM a negative one. This more elaborate model when applied to other environments gives reliable results : for example, Pouvreau et al. (1999) measured a standardised $a$-value for CR equal to $25.9 \mathrm{l} \mathrm{h}^{-1} \mathrm{~g}^{-1}$ for pearl oysters fed a concentration of Isochrysis aff. galbana equal to 8000 cell ml ${ }^{-1}$. By applying the PIM $\left(0.18 \mathrm{mg} \mathrm{l}^{-1}\right)$ and POM $\left(0.44 \mathrm{mg} \mathrm{l}^{-1}\right)$ contents of this algae suspension in our model, the calculated $a$-value averaged $25.19 \mathrm{l} \mathrm{h}^{-1} \mathrm{~g}^{-1}$, which is virtually identical to the $a$-value $\left(25.9 \mathrm{l} \mathrm{h}^{-1}\right)$ effectively measured by Pouvreau et al. (1999). This model is more precise, and strengthens the conclusion made previously by Pouvreau et la. (1999) that in poor waters 
of lagoon environment, Pinctada margaritifera succeed and grow vigorously by processing large amounts of water in order to gain sufficient energy.

Seston load is indeed well-known to influence clearance activity, but also other physiological functions. Several reviews deal with the effect of quality and quantity of suspended matter on the entire feeding behaviour and physiology of suspension-feeding molluscs (Foster-Smith, 1975; Winter, 1976; Bayne et al., 1993; De Villiers and Hodgson, 1993; Cranford and Hargrave, 1994; MacDonald and Ward, 1994; Iglesias et al., 1996; Arifin and Bendell-Young, 1997; Barillé et al., 1997a; Bayne, 1998; Cranford et al., 1998; Hawkins et al., 1998a). Nevertheless, only a few works deal with the effect of small variation in seston load (MacDonald and Ward, 1994), and no works are in the range of our study (from 0.6 to $1.2 \mathrm{mg} / \mathrm{l}$ ). In this range, PF production is the physiological function most affected in $P$. margaritifera. For TPM $<0.40 \mathrm{mg} \mathrm{l}^{-1}$, PF production was trivial, and only appeared when PIM reached $0.17 \mathrm{mg} \mathrm{l}^{-1}$ and POM $0.30 \mathrm{mg} \mathrm{l}^{-1}$. These 2 values defined the so-called pseudofaeces threshold. This threshold for Pinctada margaritifera in lagoonal environments is very low. We are not aware of other comparable data from bivalves species and usually, pseudofaeces thresholds are above $1 \mathrm{mg} \mathrm{l}^{-1}$ (see Table 3).

Above this threshold, PF production increased rapidly with increasing TPM and reached $6 \mathrm{mg} \mathrm{h}^{-1} \mathrm{~g}^{-1}$ for the highest TPM values encountered in the lagoon. Increase in PF according to the rise in seston quantity is often reported (e.g. Bayne et al., 1993; De Villiers and Hodgson, 1993; Cranford and Hargrave, 1994; MacDonald and Ward, 1994; Iglesias et al., 1996; Ward and MacDonald, 1996; Arifin and Bendell-Young, 1997; Barillé et al., 1997a; Bacon et al., 1998; Hawkins et al., 1998a). Such a finding implicates that PF production is a way for pearl oyster to regulate its ingestion in quality and/or quantity. PF were white and mainly constituted of $\mathrm{CaCO}_{3}$ (more than $80 \%$ in weight), which indicated that $P$. margaritifera were able to selectively improve the organic content of the ingested ration, relative to filtered matter, by preferentially rejecting mineral-rich particles as pseudofaeces. In an apparently unfavourable environment, fast growth in $P$. margaritifera stems from an ingenious combination between a high clearance activity and an efficient sorting ability. Nevertheless, P. margaritifera seems not to prosper in lagoon of Polynesian High Island (e.g. Tahiti, Moorea...). These lagoons are well-known to exhibit higher seston loads than in atoll lagoons, especially because of turbid freshwater inputs. It is tempting to speculate that when seston load increases strongly (10- 
$50 \mathrm{mg} \mathrm{l}^{-1}$ ), selection ability of P. margaritifera is less efficient. Further works will focus on this selection efficiency, in order to determine the optimal conditions for pearl oyster farming.

For the moment, we can give preliminary advice for pearl farming in Polynesia. Cultivated pearl oysters on long lines will process and clarify large volumes of a surrounding poor water. Such a clearance activity implies for pearl culture that local density should be avoided and concessions should be kept far from each other. In the same way, lagoon area, exposed to water current ensuring enough food renewal, would be the most appropriate farming site. In several Polynesian atolls of The Tuamotu archipelago, water exchanges and mixing are allowed by wind activity. At some occasions (El Niño events), winds are weak during several days, inducing increases in water temperature and/or stratification. Such accidents may cause mortality in pearl oyster farms, if local density is too high. Furthers works (using modelling tools) will attempt to define the optimal density necessary to ensure growth of cultivated pearl oyster according to water current.

Acknowledgements : This work was carried out at the IFREMER Pacific Oceanological Centre and was supported by the «Programme Général de Recherche sur la Nacre » and by a financial help of the French Research Minister. We would like to thank all the people from the IFREMER Pearl Oyster laboratory and especially S. Robert and X. Caisey for scuba diving assistance; M. Garnier, J. Tiapiari, G. Jonquières and H. Teissier for their useful help in sample analysis and preparation of each survey; A. Bennett and E. Fougeray for technical help in building apparatus. We would like to also thank all the SRM team and especially G. Haumany for their field assistance on Takapoto atoll. A special thanks to P. Levy and C. Bernardino for their help in diving during the last survey. This work had also benefit of the valuable comments of M. Héral, S. Legall, J. Prou, C. Bacher and S. Bougrier from CREMA in France. 


\section{REFERENCES}

Arfi, R., Guiral, D., Bouvy, M., 1993. Wind induced resuspension in a shallow tropical lagoon. Estuarine Coastal Shelf Sci. 36, 587-604.

Arifin, Z., Bendell-Young, L.I., 1997. Feeding response and carbon assimilation by the blue mussel Mytilus trossolus exposed to environmentally relevant seston matrices. Mar. Ecol. Prog. Ser. 160, 241-253.

Bacher, C., Héral, M., Deslous-Paoli, J.M., Razet, D., 1991. Modèle énergétique uniboite de la croissance des huîtres (Crassostrea gigas) dans le bassin de Marennes-Oléron. Can. J. Fish. Aquat. Sci. 48, 391-404.

Bacon, G.S., MacDonald, B.A., Ward, J.E., 1998. Physiological responses of infaunal (Mya arenaria) and epifaunal (Placopecten magellanicus) bivalves to variations in the concentration and quality of suspended particles I. Feeding activity and selection. J. Exp. Mar. Biol. Ecol. 219, 105-125.

Barillé, L., Prou, J. 1993. Modeling japanese oyster physiological processes under natural tidal variation in suspended particulate matter. ICES CM1993/F, 22, 1-12.

Barillé, L., Prou, J., Héral, M., Razet, D., 1997a. Effects of high natural seston concentration on the feeding, selection, and absorption of the oyster Crassostrea gigas (Thunberg). J. Exp. Mar. Biol. Ecol. 212, 149-172.

Barillé, L., Héral, M., Barillé-Boyer, A.L., 1997b. Modélisation de l’écophysiologie de l’huître perlière Crassostrea gigas dans un environnement estuarien. Aquat. Living Resour. 10, 31-48.

Bayne, B.L., Newell, R.C., 1983. Physiological energetics of marine molluscs. In: Saleuddin, A.S.M., Wilbur, K.M. (Eds.), The Mollusca, Vol. 4, Academic Press, London, pp. 407-515.

Bayne, B.L., 1998. The physiology of suspension feeding by bivalve molluscs: an introduction to the Plymouth « TROPHEE » workshop. J. Exp. Mar. Biol. Ecol. 219, 1-19.

Bayne, B.L., Iglesias J.I.P., Hawkins A.J.S., Navarro E., Héral, M., Deslous-Paoli, J.M., 1993. Feeding behaviour of the mussel, Mytilus edulis: responses to variations in quantity and organic content of the seston. J. Mar. Biol. Assoc. UK 73, 813-829.

Blanchot, J., Charpy, L., Le Borgne, R., 1989. Size composition of particulate organic matter in the lagoon of Tikehau atoll (Tuamotu Archipelago). Mar. Biol. 102, 329-339.

Buigues, D., 1982. Sédimentation et diagénèse des formations carbonatées de l'atoll de Mururoa (Polynésie Française) : Volume I. Th. Univ. Paris-Sud, Orsay, N³353, 203 pp.

Charpy, L., Blanchot, J., 1996. Prochlorococcus contribution to phytoplankton biomass and production of Takapoto atoll (Tuamotu Archipelago). C.R. Acad. Sc. Paris. Life Sci. 319, 131-137. 
Charpy, L., Blanchot, J., 1998. Photosynthetic picoplankton in French Polynesian atoll lagoons : estimation of taxa contribution to biomass and production by flow cytometry. Mar. Ecol. Prog. Ser. 162, 51-70.

Charpy, L., Blanchot, J., Lo, L., 1992. Contribution des cyanobactéries (Synechococcus sp.) à la production phytoplanctonique dans un lagon d'atoll fermé (Takapoto, Tuamotu, Polynésie Française). C.R. Acad. Sc. Paris Life Sci. 314, 395-401.

Charpy, L., Dufour, P., Garcia, N., 1997. Particulate organic matter in sixteen Tuamotu atoll lagoons (French polynesia). Mar. Ecol. Prog. Ser. 151, 55-65.

Coles, S.L., Strathmann, R., 1973. Observations on coral mucus «flocs » and their potential trophic significance. Limnol. Oceanogr. 18, 673-678.

Coughlan, J., 1969. The estimation of filtering rate from the clearance of suspensions. Mar. Biol. 2, 356-358.

Cranford, P.J., Gordon, D.C., 1992. The influence of dilute clay suspensions on sea scallop (Placopecten magellanicus) feeding activity and tissue growth. Neth. J. Sea Res. 30, 107-120.

Cranford, P.J., Grant, J., 1990. Particle clearance and absorption of phytoplankton and detritus by the sea scallop Placopecten magellinacus (Gmelin). J. Exp. Mar. Biol. Ecol. 137, 105-121.

Cranford, P.J., Hargrave, B.T., 1994. In situ time-series measurement of ingestion and absorption rates of suspension-feeding bivalves : Placopecten magellanicus. Limnol. Oceanogr. 39, 730-738.

Cranford, P.J., Emerson, C.W., Hargrave, B.T., Milligan, T.G., 1998. In situ feeding and absorption responses of sea scallops Placopecten magellanicus (Gmelin) to storm-induced changes in the quantity and composition of the seston. J. Exp. Mar. Biol. Ecol. 219, 45-70.

Defossez, J.M., Daguzan, J., 1995. Mesure comparative du débit palléal des bivalves Tapes decussatus et Ruditapes philippinarum lors de rapides changements de température et de turbidité. Cah. Biol. Mar. 36, 299-307.

Deslous-Paoli, J.M., Lannou, A.M., Geairon, P., Bougrier, S., Raillard, O., Héral, M., 1992. The effects of food behaviour of Crassostrea gigas (Molluscs bivalvia) on natural particulate matter biosedimentation. Hydrobiologia 231, 85-91.

De Villiers, C.J., Hodgson, A.N., 1993. The filtration and feeding physiology of the infaunal estuarine bivalve Solen cylindraceus Hanley 1843. J. Exp. Mar. Biol. Ecol. 167, 127-142.

Dufour, P., Torréton, J.P., 1996. Utilization of bacterioplankton as a food source by the pearl oyster Pinctada margaritifera. In: Lessios, H.A. (Ed.), Proc. 8th Int. Symp. Coral Reef, Panama, Abstract pp. 54.

Foster-Smith, R.L., 1975. The effect of concentration of suspension on the filtration rates and pseudofaecal 
production for Mytilus edulis L., Cerastoderma edule (L.), and Venerupis pullastra (Montagu). J. Exp. Mar. Biol. Ecol. 17, 1-22.

Haven, D.S., Morales-Alamo, R., 1970. Filtration of particles from suspension by the American oyster Crassostrea virginica. Biol. Bull. 139, 248-264.

Hawkins, A.J.S., Smith, R.F.M., Tan, S.H., Yasin, Z.B., 1998a. Suspension-feeding behaviour in tropical bivalve molluscs: Perna viridis, Crassostrea belcheri, Crassostrea iradelei, Saccostrea cucculata and Pinctada margarifera. Mar. Ecol. Prog. Ser. 166, 173-185.

Hawkins, A.J.S., Bayne, B.L., Bougrier, S., Héral, M., Iglesias, J.I.P., Navarro, E., Smith, R.F.M., Urrutia, M.B., 1998b. Some general relationships in comparing the feeding physiology of suspension-feeding bivalve molluscs. J. Exp. Mar. Biol. Ecol. 219, 87-103.

Iglesias, J.I.P, Navarro, E., Alvarez-Jorna, P., Armentia, I., 1992. Feeding, particle selection and absorption in cockles Cerastoderma edule (L.) exposed to variable conditions of food concentration and quality. J. Exp. Mar. Biol. Ecol. 162, 177-198.

Iglesias, J.I.P., Urrutia, M.B., Navarro, E., Alvarez-Jorna, P., Larretxea, X., Bougrier, S., Héral, M., 1996. Variability of feeding processes in the cockle Cerastoderma edule (L.) in response to changes in seston concentration and composition. J. Exp. Mar. Biol. Ecol. 197, 121-143.

Iglesias, J.I.P., Urrutia, M.B., Navarro, E., Ibarrola, I., 1998. Measuring feeding and absorption in suspensionfeeding bivalves : an appraisal of the biodeposition method. J. Exp. Mar. Biol. Ecol. 219, 71-86.

Johannes, R.E., 1967. Ecology of organic agregates in the vicinity of a coral reef. Limnol. Oceanogr. 12 (2), 189195.

Jonquières, G., Amouroux, J.M., Bennett, A., Blanchot, J., Bougrier, S., Buestel, D., Caisey, X., Delesalle, B., Dormoy, J.M., Dufour, P., Geairon, P., Hautefeuille, F., Loret, P., Pagès, J., Pellan, A., Pouvreau, S., Robert, S., Teissier, H., Tiapari, J., Torréton, J.P., 1995. Etude de la nutrition de l’huître perlière, Pinctada margaritifera. Action de recherche PGRN n²19., IFREMER, Tahiti, 156 pp.

Loret, P., 1998. Rôle des protistes dans la nutrition de l'huître perlière Pinctada margaritifera. Action de recherche PGRNII n¹1, CREMA, l’Houmeau, France, 38 pp.

MacDonald, B.A., Bacon, G.S.,Ward, J.E., 1998. Physiological responses of infaunal (Mya arenaria) and epifaunal (Placopecten magellanicus) bivalves to variations in the concentration and quality of suspended particles II. Absorption efficiency and scope for growth. J. Exp. Mar. Biol. Ecol. 219, 127-141. 
MacDonald, B.A., Ward, J.E., 1994. Variation in food quality and particle selectivity in the sea scallop Placopecten magellanicus (Mollusca: Bivalvia). Mar. Ecol. Prog. Ser. 108, 251-264.

Marquardt, D.W., 1963. An algorithm for least squares estimation of non-linear parameters. J. Soc. Indus. Appl. Math. 2, 431-441.

Marshall, N., 1968. Observations on organic aggregates in the vicinity of coral reefs. Mar. Biol. 2, 50-53.

Pouvreau, S., Bodoy, A., Buestel, D., 1998a. Détermination du bilan énergétique chez l’huître perlière, Pinctada margaritifera, et premier modèle écophysiologique de croissance dans le lagon d'atoll de Takapoto. Rapport IFREMER, Tahiti . RI DRV 98-01, 69 pp.

Pouvreau, S., Buestel, D., Bodoy, A., Jonquières, G., Robert, S., Tiapari, J., Haumani G., 1998b. In situ feeding processes of pearl oyster Pinctada margaritifera according to environmental conditions of Takapoto atoll. Oral communication. In: International Society for Reef Studies, European meeting, 1-4 September 1998, Programme and Abstracts. Ecole Pratique des Hautes Etudes (E.P.H.E.), Perpignan, France, pp. 148.

Pouvreau, S., Jonquières, G., Buestel, D., 1999. Filtration by the pearl oyster, Pinctada margaritifera, under conditions of low seston load and small particle size in tropical lagoon habitat. Aquaculture, in press.

Raillard, O., Deslous-paoli, J.M., Héral, M., Razet, D., 1993. Modélisation du comportement nutritionnel et de la croissance de l’huître japonaise Crassostrea gigas. Oceanologica Acta 16, 73-82.

Ross, A.H., Nibet, R.M., 1990. Dynamic models of growth and reproduction of the mussel Mytilus edulis L. Funct. Ecology 4, 777-787.

Schneider, D.W., 1992. A bioenergetics model of zebra mussel, Dreissena polymorpha, growth in the great lakes. Can. J. Fish. Aquat. Sci. 49, 1406-1416.

Sournia, A., 1976. Primary production of sands in the lagoon of an atoll and the role of foraminiferan symbionts. Mar. Biol. 37, 29-32.

Sournia, A., Ricard, M., 1976. Données sur l'hydrologie et la productivité du lagon d'un atoll fermé (Takapoto, Iles Tuamotu). Vie et milieu 26, 243-279.

Van Haren, R.J.F., Kooijman, S.A.L.M., 1993. Application of a dynamic energy budget model to Mytilus edulis (L.). Neth. J. Sea Res. 31, 119-133.

Ward, J.E., MacDonald, B.A., 1996. Pre-ingestive feeding behaviours of two sub-tropical bivalves (Pinctada imbricata and Arca zebra): responses to an acute increase in suspended sediment concentration. Bull. Mar. Sci. 59, 417-432. 
Widdows, J., 1985. Physiological procedures. In : The effects of Stress and pollution on Marine Animals. Bayne, B.L., Brown, D.A., Burns, K., Dixon, D.R., Ivanovici, A., Livingstone, D.R., Moore, D.M., Stebbing, A.R.D., Widdows, J., (Eds), Praeger Scientific, New York, pp. 161-178.

Widdows, J., Fieth, P., Worrall, C.M., 1979. Relationship between seston, available food and feeding activity in the common mussel Mytilus edulis. Mar. Biol. 50, 195-207.

Willows, R.I., 1992. Optimal digestive investment: A model for filter feeders experiencing variable diets. Limnol. Oceanogr. 37, 829-847.

Winter, J.E., 1976. A critical review on some aspects of filter-feeding in lamellibranchiate bivalves. Haliotis 7, 7187.

Yukuhira, H., Klumpp, D.W., Lucas, J.S., 1998. Effects of body size on suspension feeding and energy budgets of the pearl oysters Pinctada margaritifera and P. maxima. Mar. Ecol. Prog. Ser. 170, 119-130. 


\section{TABLES}

Table 1 : Summary of meteorological and hydrobiological parameters for each survey (mean value and range).

\begin{tabular}{|c|c|c|c|}
\hline & $\begin{array}{c}\text { Survey } 1 \\
\text { from 2/06/96 to } 10 / 06 / 96 \\
\end{array}$ & $\begin{array}{c}\text { Survey } 2 \\
\text { from 14/03/97 to } 24 / 03 / 97\end{array}$ & $\begin{array}{c}\text { Survey } 3 \\
\text { from 06/11/97 to 14/11/97 }\end{array}$ \\
\hline \multicolumn{4}{|l|}{ Meteorological parameters } \\
\hline Air temperature $\left({ }^{\circ} \mathrm{C}\right)$ & $27.4(27.2-27.5)$ & $28.1(26.6-29.1)$ & $28.3(27-29.1)$ \\
\hline Duration of sunshine (h) & $9.6(8.1-10.2)$ & $8.8(4.1-11.1)$ & $8.2(0-10.5)$ \\
\hline Precipitations (mm) & $3.1(0-2)$ & $90.2(0-42.7)$ & $95.8(0-45.4)$ \\
\hline Atmospheric pressure (hPa) & $1012.8(1011.8$ - 1014.8) & $1011.9(1008.5$ - 1015.4) & $1014.5(1012.6$ - 1015.6) \\
\hline Wind direction & NE & NW / SW & SE \\
\hline Wind speed $\left(\mathrm{km} \mathrm{h}^{-1}\right)$ & $23(7-40)$ & $16(0-36)$ & $18(0-40)$ \\
\hline \multicolumn{4}{|l|}{ Hydrobiological parameters } \\
\hline Water temperature $\left({ }^{\circ} \mathrm{C}\right)$ & $27(26.5-27.5)$ & $30(27.5-31.5)$ & $29(27-2$ 9.5) \\
\hline Salinity (ppt) & $38(37.8-38.2)$ & $39(38.7-39.1)$ & $38(37.8-38.2)$ \\
\hline Oxygen pressure & over saturation & over saturation & over saturation \\
\hline TPM (mg l $\left.{ }^{-1}\right)$ & $1.00(1.10-0.93)$ & $1.05(0.81-1.25)$ & $\mathbf{0 . 8 9}(0.70-1.29)$ \\
\hline PIM (mg I I ) & $\mathbf{0 . 3 7}(0.26-0.48)$ & $\mathbf{0 . 4 8}(0.33-0.46)$ & $0.38(0.28-0.63)$ \\
\hline POM (mg I $\left.{ }^{-1}\right)$ & $\mathbf{0 . 6 3}(0.61-0.66)$ & $\mathbf{0 . 5 8}(0.54-0.48)$ & $0.51(0.42-0.66)$ \\
\hline OC (\%) & 63 & 55 & 57 \\
\hline
\end{tabular}


Table 2 : Coefficient correlation (r) matrix (Pearson coefficient) between physiological function and independent variables. Values in italic are the significance level $(P)$ associated to the $r$-value (i.e. $P$-value below 0.05 indicates that the estimated r-value is reliable and that the two variables are correlated).

\begin{tabular}{|c|c|c|c|c|c|}
\hline Physiological functions & $\mathbf{W}$ & TPM & POM & PIM & OC \\
\hline CR & $\begin{array}{c}0.7901 \\
0.00\end{array}$ & $\begin{array}{c}0.1019 \\
0.16\end{array}$ & $\begin{array}{c}0.3227 \\
0.00\end{array}$ & $\begin{array}{c}-0.0804 \\
0.05\end{array}$ & $\begin{array}{c}0.2903 \\
0.00\end{array}$ \\
\hline PF & $\begin{array}{c}0.5223 \\
0.00\end{array}$ & $\begin{array}{c}0.6207 \\
0.00\end{array}$ & $\begin{array}{c}0.4345 \\
0.00\end{array}$ & $\begin{array}{c}0.6017 \\
0.00\end{array}$ & $\begin{array}{c}-0.4070 \\
0.00\end{array}$ \\
\hline $\mathbf{P F}_{\text {PIM }}$ & $\begin{array}{c}0.5137 \\
0.00\end{array}$ & $\begin{array}{c}0.6321 \\
0.00\end{array}$ & $\begin{array}{c}0.4535 \\
0.00\end{array}$ & $\begin{array}{c}0.6050 \\
0.00\end{array}$ & $\begin{array}{c}-0.4001 \\
0.00\end{array}$ \\
\hline $\mathbf{P F}_{\text {POM }}$ & $\begin{array}{c}0.5521 \\
0.00\end{array}$ & $\begin{array}{c}0.5038 \\
0.00\end{array}$ & $\begin{array}{c}0.2717 \\
0.00\end{array}$ & $\begin{array}{c}0.5462 \\
0.00\end{array}$ & $\begin{array}{c}-0.4377 \\
0.00\end{array}$ \\
\hline $\mathbf{F}$ & $\begin{array}{c}0.7204 \\
0.00\end{array}$ & $\begin{array}{c}0.4263 \\
0.00\end{array}$ & $\begin{array}{c}0.3647 \\
0.00\end{array}$ & $\begin{array}{c}0.3661 \\
0.00\end{array}$ & $\begin{array}{c}-0.1959 \\
0.01\end{array}$ \\
\hline $\mathbf{F}_{\text {PIM }}$ & $\begin{array}{c}0.6968 \\
0.00\end{array}$ & $\begin{array}{c}0.4357 \\
0.00\end{array}$ & $\begin{array}{c}0.3825 \\
0.00\end{array}$ & $\begin{array}{c}0.3672 \\
0.00\end{array}$ & $\begin{array}{c}-0.1872 \\
0.01\end{array}$ \\
\hline $\mathbf{F}_{\text {POM }}$ & $\begin{array}{c}0.7674 \\
0.00\end{array}$ & $\begin{array}{c}0.3219 \\
0.00\end{array}$ & $\begin{array}{c}0.2202 \\
0.00\end{array}$ & $\begin{array}{c}0.3158 \\
0.00\end{array}$ & $\begin{array}{c}-0.2217 \\
0.00\end{array}$ \\
\hline
\end{tabular}


Table 3 : Value of pseudofaeces threshold and PF production among several bivalves species under low turbidity environment. Pinctada margaritifera produces pseudofaeces at very low seston level

\begin{tabular}{|c|c|c|c|c|c|c|}
\hline Species & Food & $\begin{array}{l}\text { Range of seston load } \\
\left(\mathbf{m g ~ ~ ^ { 1 } )}\right.\end{array}$ & $\begin{array}{l}\text { Organic content of } \\
\text { seston (\%) }\end{array}$ & $\begin{array}{c}\text { Pseudoafeces } \\
\text { threshold (mg l) }\end{array}$ & $\begin{array}{l}\text { PF production } \\
\left(\mathrm{mg} \mathrm{h}^{-1} \mathrm{~g}^{-1}\right)\end{array}$ & References \\
\hline Mytilus edulis & natural seston & & & 2.6 & & Widdowset al. (1979) \\
\hline$"$ & $\begin{array}{l}\text { experimental diet close to } \\
\text { natural conditions }\end{array}$ & $1-10$ & $50-70$ & 3 & $0-2$ & Bayne et al. (1993) \\
\hline Mytilus trossolus & $\begin{array}{l}\text { experimental diet close to } \\
\text { natural conditions }\end{array}$ & $1.4-15.7$ & $60-70$ & $>1.4$ & $0-29.6$ & Arifin and Bendell-Young (1997) \\
\hline Crassostrea virginica & natural seston & & & 3 & & Haven and Morales-Alamo (1966) \\
\hline Crassostrea gigas & natural seston & 10 & & 4.6 & 18 & Deslous-paoliet al. (1992) \\
\hline Cerastoderma edule & natural seston & & & $>3$ & & Iglesiaset al. (1996) \\
\hline Arca zebra & natural seston & $3-12$ & $20-30 *$ & $>3.1$ & $0-1$ & Ward and MacDonald (1996) \\
\hline Solen cylindraceus & natural seston & & & $\sim 5$ & & DeVilliers and Hodgson (1993) \\
\hline Mya arenaria & $\begin{array}{l}\text { experimental diet close to } \\
\text { natural conditions }\end{array}$ & $1-14$ & 50 & $\sim 1$ & $0.1-0.3$ & Baconet al. (1998) \\
\hline Placopecten magellanicus & $\begin{array}{l}\text { experimental diet close to } \\
\text { natural conditions }\end{array}$ & $1-14$ & 50 & $\sim 1$ & $2-10$ & Baconet al. (1998) \\
\hline$"$ & natural seston & $1-2.5$ & $45-65$ & $>3$ & 0 & Cranford and Hargrave (1994) \\
\hline Pinctada imbricata & natural seston & $3-12$ & $20-30 *$ & $>3.1$ & $4.8-16^{*}$ & Ward and MacDonald (1996) \\
\hline Pinctada margaritifera & natural seston & $0.4-1.5$ & $50-60$ & $>0.4$ & $0-10.2$ & This study \\
\hline
\end{tabular}




\section{FIGURES}

Fig. 1 : Processing of water and path of the retained particulate matter in the pearl oyster.

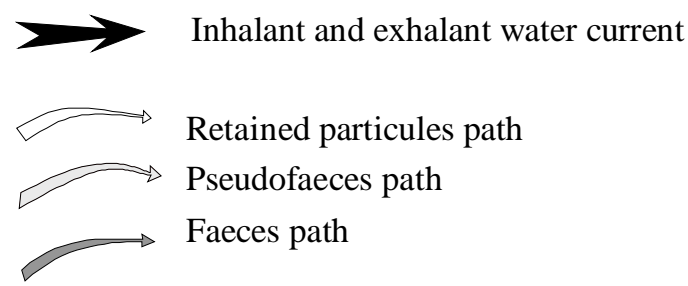

Fig. 2 : Simultaneous variations between seston load (TPM, PIM and POM +/- CI) and wind velocity for each survey. Small hodogram graphs integrate speed and direction of wind during each survey.

Fig. 3: Physiological responses (CR, PF and F production) according to pearl oyster weight and TPM load ( : $\left.\mathrm{TPM}<1 \mathrm{mg} \mathrm{l}^{-1} ; \mathrm{O}: \mathrm{TPM}>1 \mathrm{mg} \mathrm{l}^{-1}\right)$.

Fig. 4 : Comparison between estimation obtained by models and field observation. The fine line corresponds to the equation $\mathrm{y}=\mathrm{x}$.

Fig. 5 : Tri-dimensional pattern for the main feeding processes (CR, PF and F) : (A) : 3D representation for CR model according to PIM/POM realistic concentration and body size W; (B) : 3D representation for standardised CR model according to PIM/POM realistic concentration; (C and D) : 3D representation for mineral and organic PF production models; (E and F) : 3D representation for mineral and organic F production models.

Fig. 6 : Organic content (OC, \%) of TPM in water, of the rejected and the egested ration according to the increase in TPM concentration in water. $\mathrm{OC}_{\mathrm{PF}}$ and $\mathrm{OC}_{\mathrm{F}}$ are considerably lower than $\mathrm{OC}$ in water. 
Figure 1

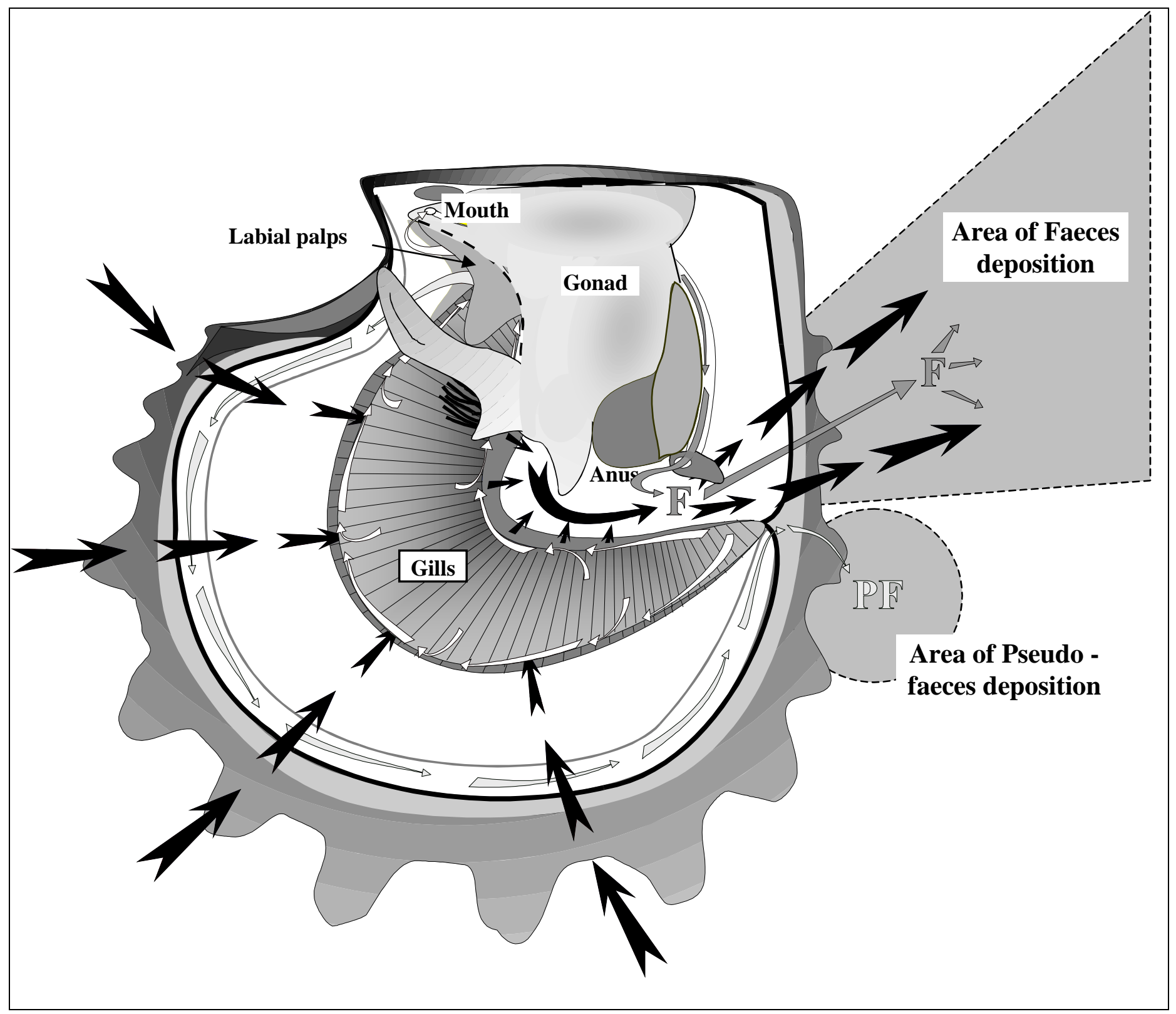

(C) IFREMER 1994, D. Buestel and S. Pouvreau 
Figure 2
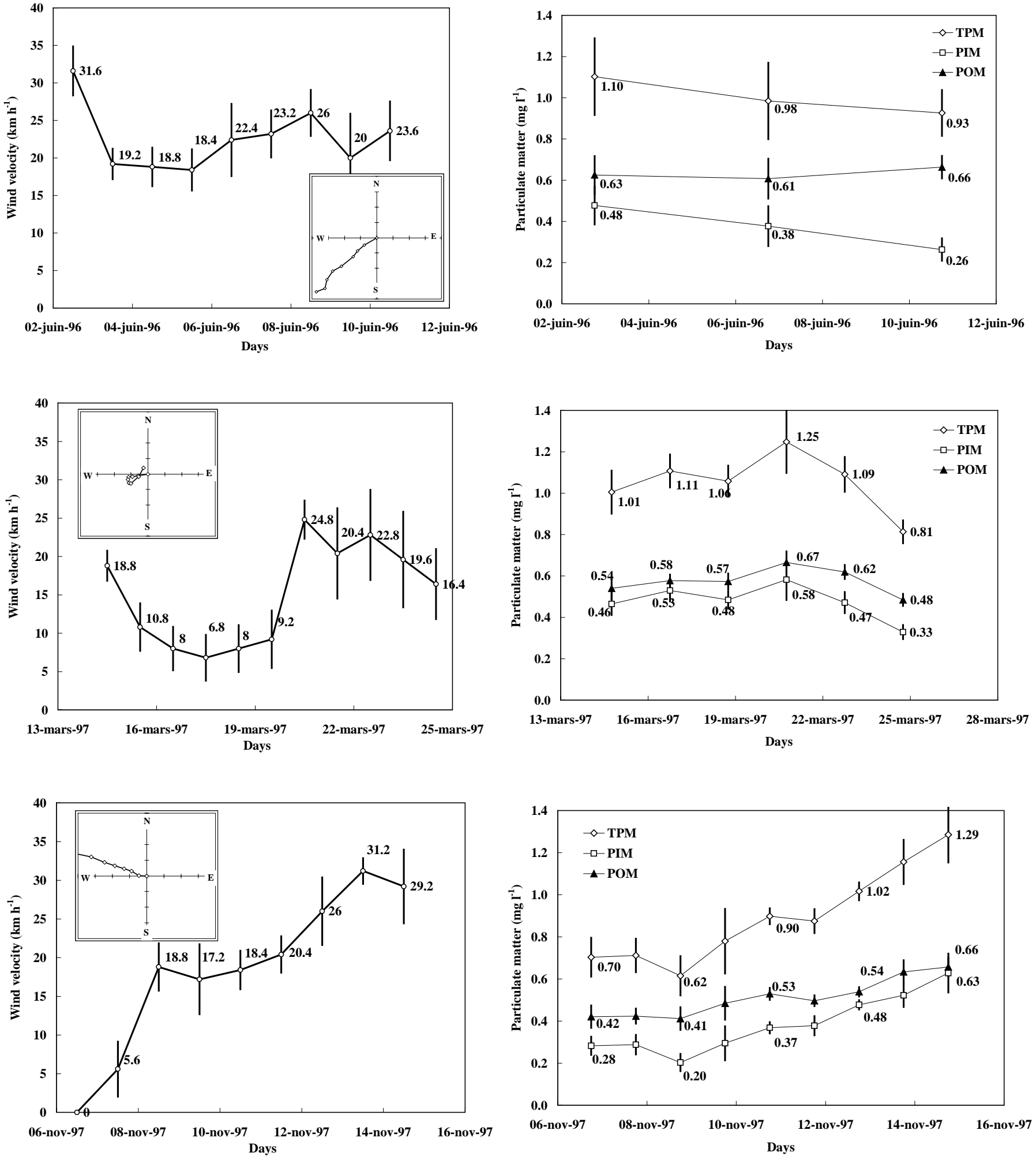

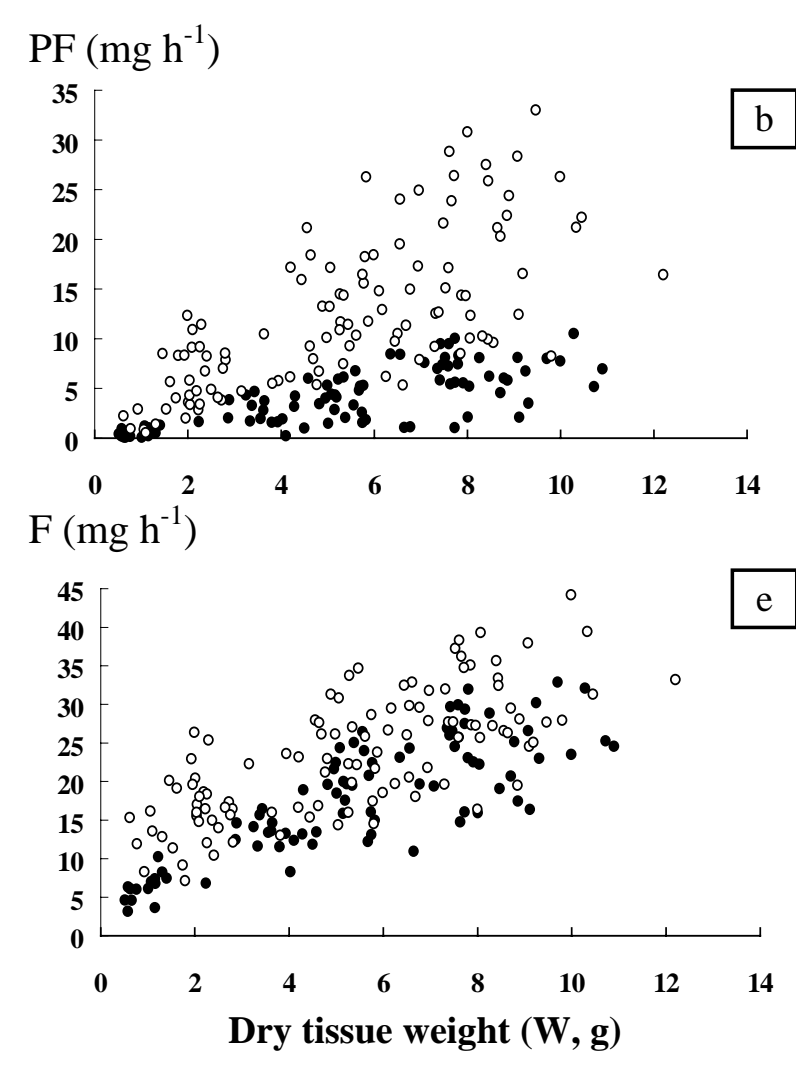

$$
\mathrm{CR}\left(\mathrm{l} \mathrm{h}^{-1}\right)
$$

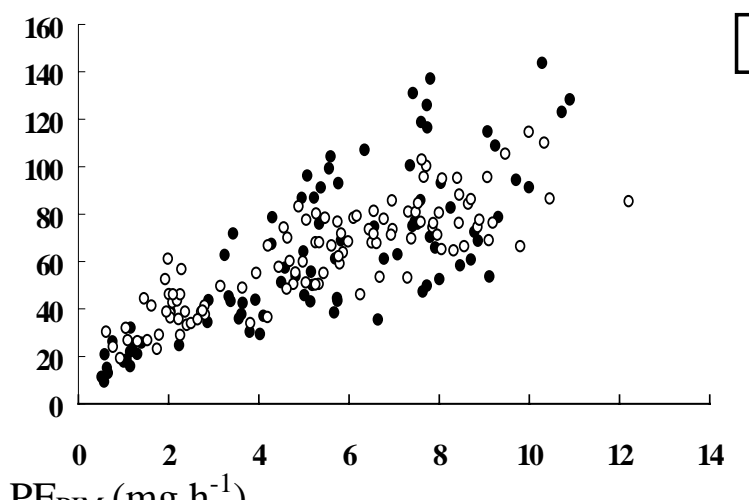

$\operatorname{PF}_{\text {PIM }}\left(\mathrm{mg} \mathrm{h}^{-1}\right)^{4}$

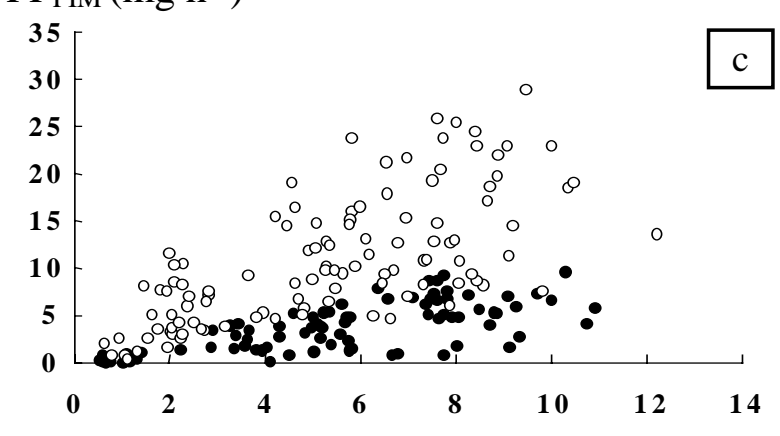

$\mathrm{F}_{\mathrm{PIM}}\left(\mathrm{mg} \mathrm{h}^{-1}\right)$

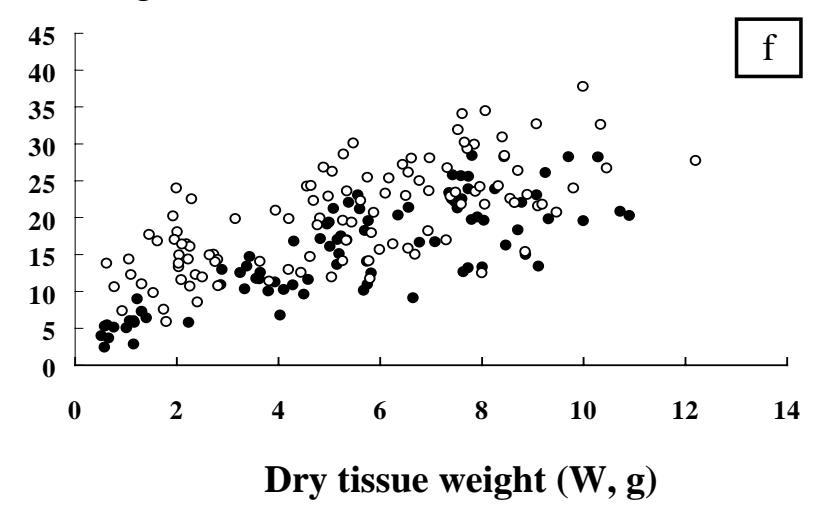

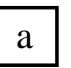

$\mathrm{PF}_{\text {POM }}\left(\mathrm{mg} \mathrm{h}^{-1}\right)$

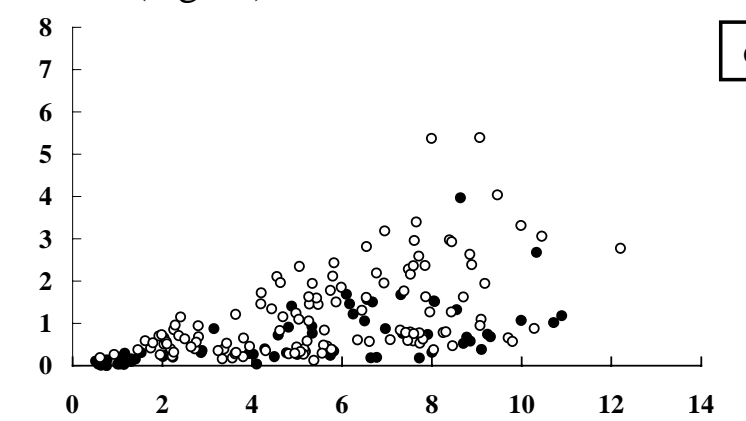

\section{$\mathrm{F}_{\mathrm{POM}}\left(\mathrm{mg} \mathrm{h}^{-1}\right)$}

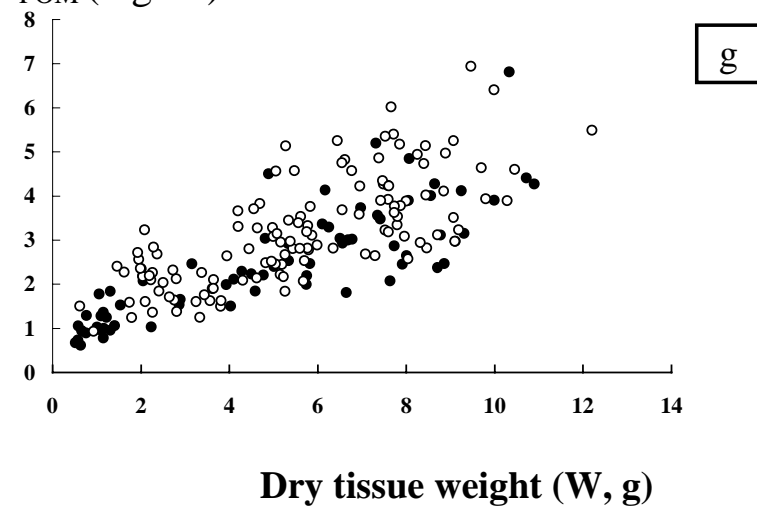


Figure 4
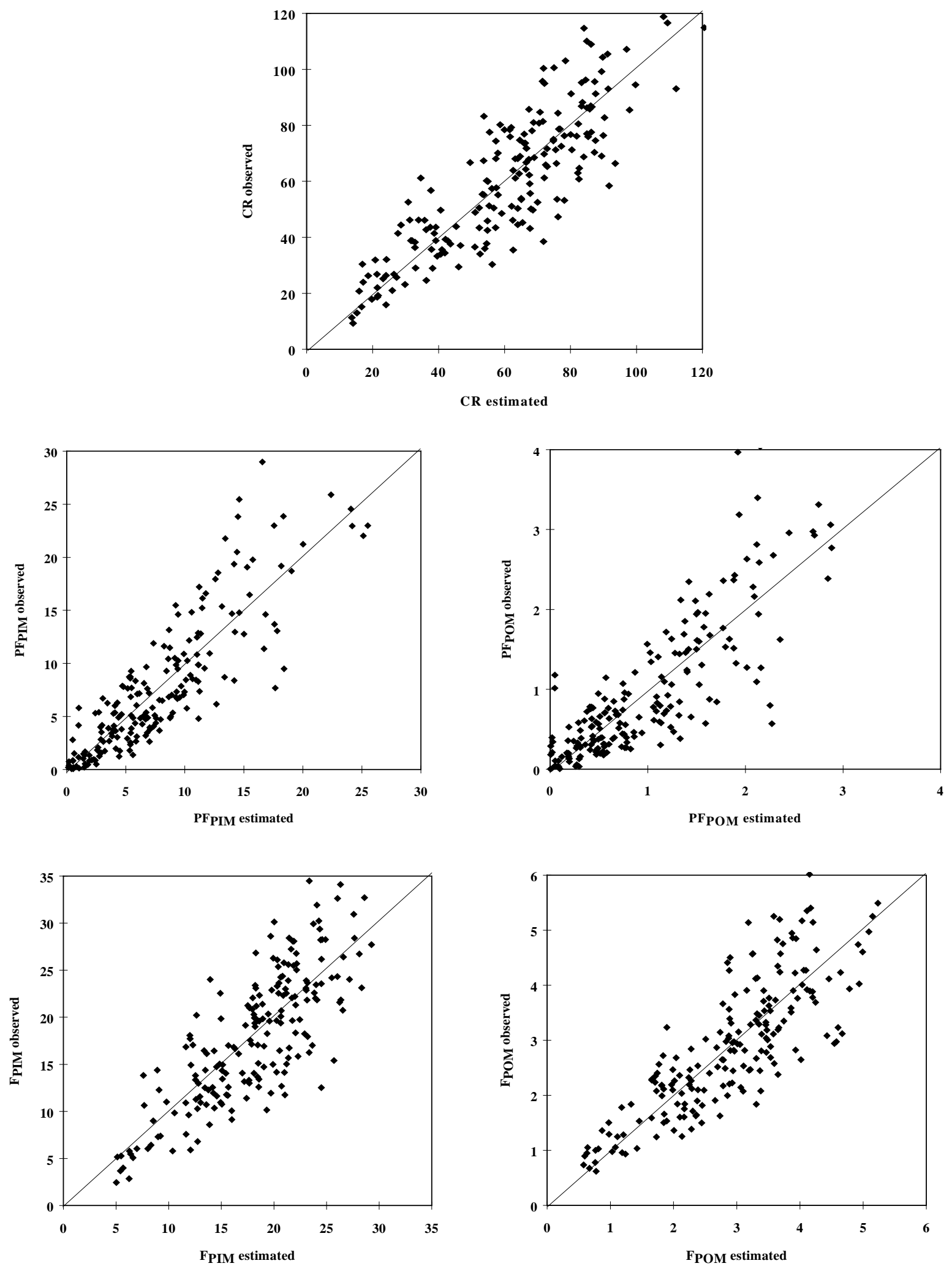
Figure 5 (to be published in black and white)
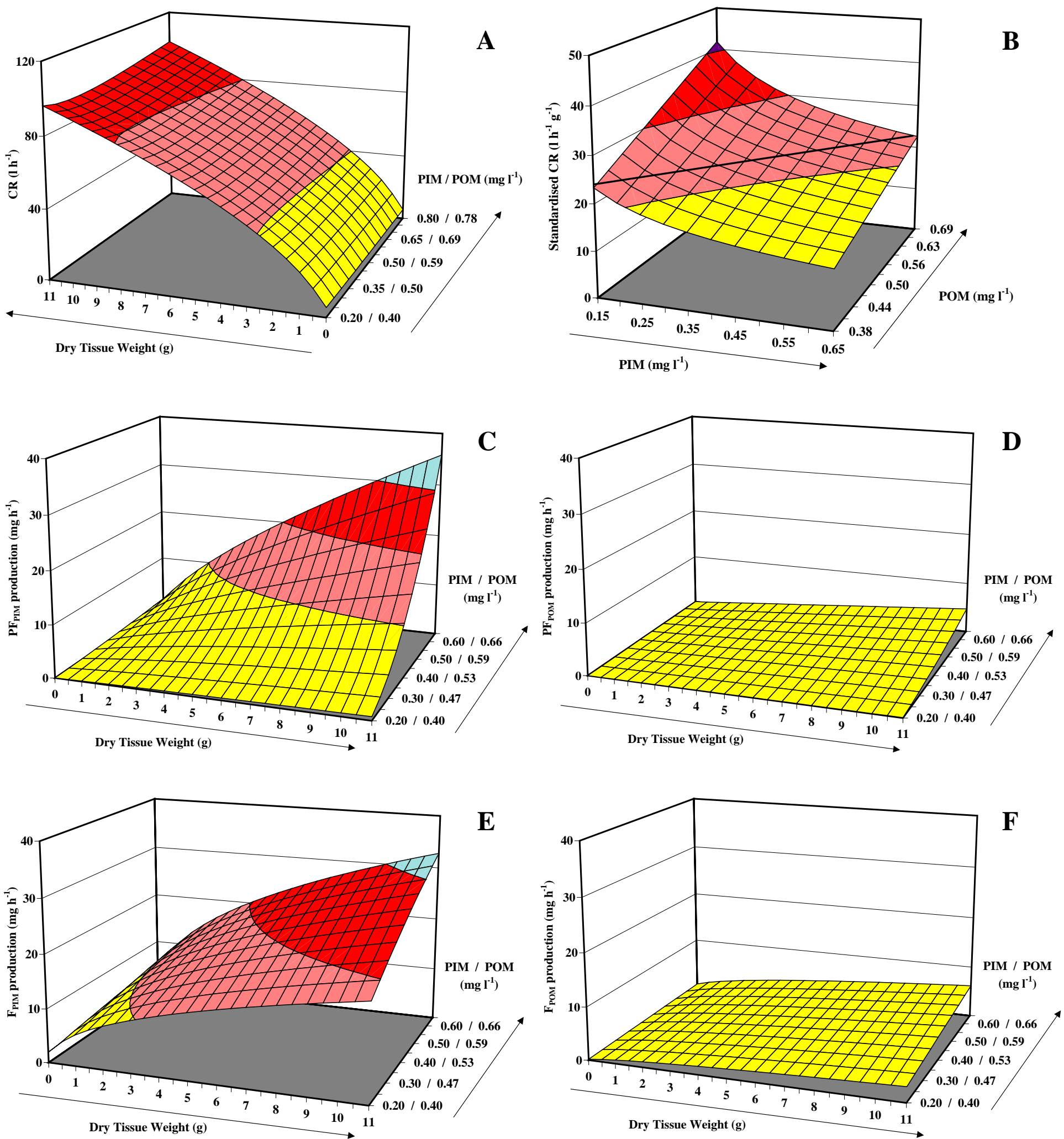
Figure 6

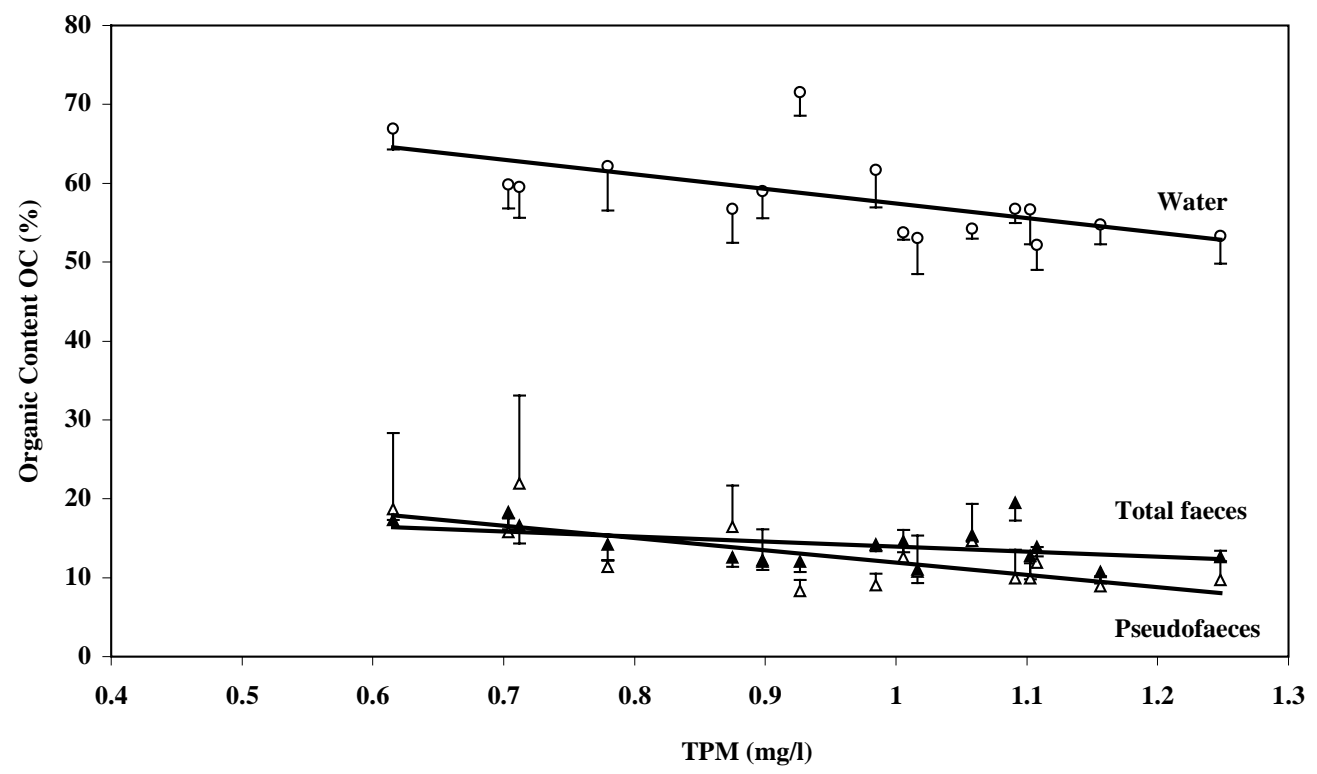

